\title{
Wildlife Hunting and Utilization in Ulu Baleh, Sarawak, Malaysian Borneo
}

\author{
Melynda Cheok Ka Yi ${ }^{1}$ and Jayasilan Mohd-Azlan ${ }^{2 *}$ \\ ${ }^{1}$ Faculty of Resource Science and Technology, Universiti Malaysia Sarawak, Sarawak, Malaysia. ${ }^{2}$ Institute of Biodiversity and \\ Environmental Conservation, Universiti Malaysia Sarawak, Sarawak, Malaysia. \\ *azlan@unimas.my
}

\begin{abstract}
Poaching is one of the greatest immediate threats and a serious conservation challenge facing wildlife in Borneo. Medium- to large-sized mammals, while charismatic, are hunted for consumption and sale. This study focuses on wildlife hunting and utilization of selected communities in a remote area in Sarawak, conducted using interview surveys within communities who hunt wildlife in Ulu Baleh. The calculated hunting pressure index in Ulu Baleh (2.24) is considered low compared to other parts of Sarawak. Local communities are dependent on wildlife protein and medicine. Even though the common hunting offtake included the bearded pig and deer species, for the hunter's own consumption, hunters were opportunistic in taking non-target species and selling surplus meat. Lack of awareness of the implications of unsustainable hunting and difficulty in monitoring by the relevant authorities appear to be the main challenges to wildlife conservation in the area. This paper highlights the lack of research documenting wildlife utilization in the Ulu Baleh region and the implication of these results are particularly important for future adaptive wildlife management, especially for species of conservation importance in Sarawak.
\end{abstract}

Received September 8, 2019

OPEN ひACCESS

Accepted June 12, 2020

DOI 10.14237/ebl.11.1.2020.1647

Published September 15, 2020

Keywords Hunting, Conservation, Wildlife utilization, Ulu Baleh, Sarawak

Copyright (C) 2020 by the author(s); licensee Society of Ethnobiology. This is an open-access article distributed under the terms of the Creative Commons Attribution-NonCommercial 4.0 International Public License (https://creativecommons.org/licenses/by-nc/4.0), which permits non-commercial use, distribution, and reproduction in any medium, provided the original author and source are credited.

Supplementary Files available at https://doi.org/10.14237/ebl.11.1.2020.1647

\section{Introduction}

Although Hunting can be unsustainable in many areas, including in indigenous hunting areas when hunting pressure is unacceptably high (Pangau-Adam et al. 2012; Robinson and Bennett 2000). Humans have used animals for food, medicine, garments, tool manufacturing, as well as cultural-religious practices (Bennett et al. 2000; Melo et al. 2014; Mohd-Azlan and Fauzi 2006). Likewise, terrestrial vertebrate fauna have been utilized for various reasons, including subsistence, economy, pest control, as well as cultural needs (Bennett et al. 2000). Such uses have often affected targeted species, sometimes leading to their endangerment, especially those with low density and/ or slow reproductive rates (Melo et al. 2014; PangauAdam et al. 2012). Moreover, increases in human population, improved hunting techniques and gear, modern transportation, ease of accessibility along logging road networks, and increased economic benefits have led to increased hunting pressures (Bennett et al. 2000; Pangau-Adam et al. 2012). Human innovations in technology have fueled cultural advancement, but also expanded wildlife utilization in tropical forests (Chin 2001).

Three pieces of legislation exist for wildlife conservation in Malaysia: the Sarawak Wild Life Protection Ordinance (SWLPO) 1998 in Sarawak, Wildlife Conservation Enactment (WCE) 1997 in Sabah, and Wildlife Conservation Act (WCA) 2010 in Peninsular Malaysia. The WCE and WCA are rather comprehensive and have been recently amended, whereas SWLPO is currently being reviewed by the relevant authorities (Mohd-Azlan 2014). Local communities in Sarawak are allowed to hunt unprotected species (e.g., bearded pig [Sus barbatus], 